\title{
Çevrim İçi Bir Öğrenme Ortamı Olarak eTwinning Platformuna İlişkin Öğretmenlerin Görüş ve Değerlendirmeleri*
}

\section{Fatma Avc1 ${ }^{1}$}

\section{Type/Tür:}

Research/Araştırma

Received/Geliş Tarihi: December

23/ 23 Aralık 2019

Accepted/Kabul Tarihi:

November 10/ 10 Kasim 2020

Page numbers/Sayfa No: $1-22$

Corresponding

Author/İletişimden Sorumlu

Yazar: fatma.epo@gmail.com

\section{$\checkmark$ iThenticate $^{\circ}$}

This paper was checked for plagiarism using iThenticate during the preview process and before publication. / Bu çalışma ön inceleme sürecinde ve yayımlanmadan önce iThenticate yazılımı ile taranmıştır.

Copyright (c) 2017 by Cumhuriyet University, Faculty of Education. All rights reserved.

\section{$\ddot{O ̈ z}$}

$\mathrm{Bu}$ araştırmanın temel amacı eTwinning platformuna ilişkin platformun kullanıcıları olan öğretmenlerin görüş ve değerlendirmelerini belirlemek yanı sıra öneriler geliştirmektir. $\mathrm{Bu}$ araştırma nitel bir durum çalışmasıdır. Araştırmanın temel amacı doğrultusunda katılımcı öğretmenlerle yarı yapılandırılmış görüşmeler yapılmıştır. Araştırmaya okul öncesi ve sınıf öğretmenliği branşlarından toplamda 20 öğretmen katılmıştır. Verilerin çözümlenmesinde betimsel analiz tekniğinden yararlanılmıştır. Araştırma sonunda bazı öğretmenlerin eTwinning platformunun kullanılabilirliğine yönelik olarak platformun işleyişini anlamakta zorlandıkları ve kullanımını kolay bulmadıkları anlaşılırken bazı ögretmenlerin de kullanım konusunda zorluk yaşamadıkları ortaya çıkmıştır. Öğretmenler mesleki gelişim açısından platformu kullanışlı bulmuşlar, özellikle meslektaşlarıyla işbirliği yapabildiklerini ve bu yolla meslektaşlarından yeni yaklaşım ve yöntemler öğrendiklerini, çeşitli Web 2 araçlarını öğrenerek mesleki gelişimlerini sağladıklarını ve eğitim öğretim sürecinde de kullandıklarını belirtmişlerdir. Araştırmanın katılımcıları olan öğretmenler eTwinning projesinin daha da yaygınlaştırılmasını önermişler, bu konuda destekleyici hizmet içi eğitimlerin verilmesi, proje yazım süreci ve kalite etiketine başvuru süreci hakkında bilgilendirmelerin artmasının gerektiğini belirtmişlerdir. Katılımcı öğretmenler eTwinning platformunda oluşturdukları projelerin Milli Eğitim Bakanlığı Bilgi Sistemi'ne (MEBBi̇S) kaydedilmesini ve bu yönde hem okul yönetimi hem de velileri tarafından desteklenmek istediklerini ifade etmişlerdir. Araştırma ile eTwinning platformuna yönelik araştırmalar yapan araştırmac1, öğretmen ve yöneticilere yol gösterilmesi, platform hakkında detaylı bilgi verilmesi hedeflenmiştir. Temel kullanıcıları olan öğretmenlerin bakış açısıyla platformun ortaya konulması yönüyle de araştırma özgün ve önemlidir.

Anahtar Kelimeler: eTwinning, proje, öğretmenler, değerlendirme

\section{Suggested APA Citation/Önerilen APA Atıf Biçimi:}

Avcı, F. (2021). Çevrim içi bir öğrenme ortamı olarak etwinning platformuna ilişkin öğretmenlerin görüş ve değerlendirmeleri. Cumhuriyet International Journal of Education, 10(1), 1-22. http://dx.doi.org/10.30703/cije.663472

1Dr., Milli Eğitim Bakanlığı, Eskişehir/Türkiye e-mail: fatma.epo@gmail.com ORCID ID: orcid.org/0000-0002-7513-9870

*II. UTEK- 2. Uluslararası Temel Eğitim Kongresi'nde (23-27 Ekim 2019) sözlü bildiri olarak sunulmuştur. 


\title{
Teachers Opinions and Assessments on the eTwinning Platform as an Online Learning Environment
}

\begin{abstract}
The main purpose of this research is to determine the opinions and evaluations of the teachers who are users of the platform regarding the eTwinning platform, as well as to develop suggestions. This research is a qualitative case study. In line with the main purpose of the study, semi-structured interviews were conducted with the participating teachers. A total of 20 teachers from preschool education and primary school teaching majors participated in the study. Descriptive analysis technique was used in analyzing the data. At the end of the research, it was revealed that some teachers had difficulty in understanding the functioning of the eTwinning platform in terms of its usability and did not find it easy to use, but some teachers did not have difficulty in using it. Teachers found the platform useful in terms of professional development, they stated that they could especially cooperate with their colleagues and learn new approaches and methods from their colleagues in this way, they provided their professional development by learning various Web 2 tools and they also used them in the education and training process. The teachers, who were the participants of the present research, suggested that the eTwinning project should be expanded further, and they stated that they should be informed about the supportive in-service training, project writing process and the application process for the quality label. Participating teachers stated that they want the projects they have created on the eTwinning platform to be registered in the Information System of the Ministry of National Education (MEBBİS) and to be supported by both the school administration and students' parents in this direction. With the research, it is aimed to guide researchers, teachers and administrators who conduct research on the eTwinning platform and to provide detailed information about the platform. The current research is original and important in terms of introducing the platform from the perspective of teachers, who are its main users.
\end{abstract}

Keywords: eTwinning, project, teachers, evaluation

\section{Giriş}

Son zamanlarda yeni gelişen teknolojilerle birlikte çevrim içi öğrenme ortamları da hızlı bir artış göstererek giderek yaygınlaşmıştır. Çevrimiçi öğrenme ortamları, bireylere kendilerini yetiştirme konusunda çok geniş ve önemli fırsatlar sunmakta; (Gülbahar, 2017; Zengin ve Can, 2010) öğretmenlere ve öğrencilere geleneksel sinıflarda mümkün olmayan bir dizi yeni ve heyecan verici tecrübeler de sunmaktadır (Hadjerrouit, 2010). Bu bağlamda geleneksel öğrenme ortamlarının sağlayamadığı esnek katılım ve zaman-mekândan bağımsız eğitim gibi önemli olanaklar sayesinde öğrenme süreçlerine katkı sağlayarak bireylere etkin bir e-öğrenme firsatı yaratmaktadır (Halttunen ve Jarvelin, 2005; Miyazoe ve Anderson, 2010).

eTwinning Projesi, e-öğrenme projesinin önemli bir ürünü olarak 2005 yılının ocak ayında Brüksel'de yapılan bir konferansla uygulamaya konulmuştur. En az iki farklı Avrupa ülkesinden ve en az iki okul arasındaki çevrimiçi temelli projeleri destekleyen bir uygulama olan eTwinning portalı Avrupa Birliği'nin Erasmus+ programı çerçevesinde yürütülmektedir (Kearney ve Gras-Velasquez, 2015). Ulusal düzeyde otuz yedi ülkenin Ulusal Destek Servisi tarafından desteklenmektedir ve portal kullanıcılarına yirmi sekiz farklı dilde hizmet vermektedir. Türkiye ise $2009^{\prime}$ da bu ă̆ın bir parçası haline gelmiştir ve "eTwinningErasmus+" tanıtım rehberinde de anaokulu, ilkokul, ortaokul ve liselerdeki öğretmen ve öğrencilere sanal işbirliği için bir alan sağlayan bir "IT destek platformu" olarak tanımlanmaktadır (Erasmus+, 2016). eTwinning en sade tanımıyla, iletişim kurmak, 
işbirliği yapmak, projeler geliştirmek, paylaşmak; kısacası Avrupa'daki öğrenme topluluğunun bir parçası olmak için, Avrupa ülkelerindeki katılımcı okullardan birinde çalışan personele (öğretmenler, müdürler, akademisyenler v.b.) yönelik oluşturulmuş çevrim içi bir platformdur ve kullanıcılarına proje tabanlı uygulamalar yoluyla eğitim olanakları tanımaktadır. Portalda öğretmenlere yönelik çevrim içi seminerler gibi öğretmenlerin gelişimine destek olan ve dolaylı olarak da öğrencilere destek olacak aktiviteler sunulmaktadır. eTwinning portalının bugün 573.000'i geçkin öğretmen üyesi bulunmaktadır. Portalda, öğretmenlerin projeler oluşturarak ortaklar bulmalarında, fikirlerini paylaşmalarında, yenilikçi uygulamalar alışverişinde bulunmalarında ve platformda bulunan çeşitli özelleştirilmiş araçları kullanarak çeşitli ülkelerdeki meslektaşlarıyla iletişime geçip birlikte çalışmaya başlamaları için çevrimiçi araçlar sunulmaktadır. eTwinning portalı üç bölümden oluşmaktadır. Bunlar;

1. eTwinning Ana Sayfa: $\mathrm{Bu}$ bölümde öğretmenler ilgilerini çeken projeleri inceleyebilir, Avrupa'daki okulları bulabilir, eğitim alanında ki yeni eğilimler ve yöntemler ile güncel gelişmeleri takip edebilir, oluşturulan etkinliklerden haberdar olabilir ve eTwinning oluşumu ile ilgili ihtiyaç duydukları genel ve teknik desteği alabilirler.

2. eTwinning Live: Sadece eTwinning portalına kaydolan öğretmenlerin erişebildiği kısımdır. Öğretmenler burada kendi projelerini oluşturduktan ve Türkiye Ulusal Destek Servisi'nden projeleri onaylandiktan sonra projelerine ortaklar bulabilir, üye ülkelerden ve kendi ülkelerinden meslektaşları ile mesajlaşarak iletişime geçebilirler. Platform aracılığıyla oluşturulan eğitim gruplarına katılabilir, mesleki gelişim fırsatlarına ulaşabilir ve kayıtlı tüm öğretmenlerin katılımıyla canlı etkinlikler düzenleyerek projelerini yürütebilirler. Ayrıca eğitim etkinlikleri oluşturabilir, oluşturulan etkinliklere katılarak uygulamalarını paylaşabilirler.

3. eTwinning Twinspace: eTwinning platformunda oluşturulan projelerin özel alanıdır da denilebilir. Sadece yöneticiler, proje kurucuları, proje ortakları ve öğrencilerin erişimine izin verilerek ve projelerin tüm paylaşımları burada yayınlanmaktadır.

eTwinning platformu öğretmenlere bir yandan proje kitleri ve başarılı uygulama örneklerinden oluşan bir galeri ile kendi projelerini tasarlayıp yürütme fırsatını sunarak projelerin başarı ile tamamlanmasının ardından Avrupa ve Ulusal kalite ödülleri ile kendilerinin ve okullarının tanınmasını sağlarken diğer yandan da çevrim içi öğrenme etkinliklerine katılmalarına imkan sağlayarak mesleki gelişimlerini sürdürmelerinde ve eTwinning özel etkinlikleri aracılığıyla sınıflarında uyguladıkları eğitim yöntemlerini geliştirmeye yardımcı olabilecek bilgilere ulaşmalarında etkili olmaktadır.

Teknolojik gelişme, interaktif uzaktan eğitim, çevrimiçi öğrenme, küreselleşme, yaşam boyu öğrenme, uluslararası eğitim, alternatif ölçme değerlendirme yaklaşımları, kültür-toplum-sosyallik, öğrenmeyi öğrenme becerileri, değerler eğitimi, dil temalarının 21. yüzyıl eğitimi için belirleyici kavramlar olacağı araştırmalarda vurgulanmaktadır (Gelen, 2017; Pedro, 2006). eTwinning ise, öğrencilerin eTwinning projeleri aracılı̆̆1 ile birbirlerini tanımalarını sağlarken ve öğretmenlerin de Avrupa'daki öğretmen topluluklarının bir parçası olarak farklı ülkelerde ki meslektaşları ile iletişim ve işbirliği kurmaları için fırsatlar sunmakta; iletişim, işbirliği, yabancı dil becerilerinin gelişimi, bilgi ve teknoloji okuryazarlığ1 (Kylonen, 2012; Partnership for 21st Century Learning, 2007; Trilling ve Fadel, 2009), çok kültürlü zemin (Cansoy, 2018), küresel yetkinlikler gibi (Sayın ve Seferoğlu, 2016) 21. yüzyıl eğitimi tanımlamalarında yer bulan pek çok alanda 
gelişimlerine destek olmaktadır. Temmuz 2019 tarihi itibariyle 2009 y1lından bu yana platforma Türkiye'den 174.542 öğretmen ve 43.519 okul kaydolmuş ve toplamda 31.480 proje üretilmiştir. Türkiye'de eTwinning projesi giderek büyüyen bir yapıya sahip olmasına rağmen Kearney ve Gras-Velasquez'in (2015) eTwinning'in 10. yılı için hazırladıkları rapor haricinde projenin işleyişi ve çıktılarının değerlendirildiği çalışmalarda Türkiye'nin eTwinning projesindeki yerine değinilmemektedir (Bozdağ, 2017).

eTwinning platformu işbirlikli projelere olanak sağlamasının yanı sıra öğretmenler için nitelikli mesleki gelişim fırsatları da sunmaktadır. Kendi kendini değerlendirme araçları (MeTP) ve kendi Kendine Eğitim Materyalleri, çevrimiçi seminerler, öğrenme etkinlikleri ve özel eTwinning etkinlikleri aracılığıyla akran destekli öğrenmeye kadar; öğretmenlerin eğitim yöntemlerini geliştirmelerine yardımcı olacak çok sayıda araç, platformun olanaklarına dâhildir. Platform bu çok yönlü yapısı ile eğitimcilerin yaşam boyu öğrenme becerilerini de destekleyebilmektedir (Y1lmaz ve Altun Y1lmaz, 2012).

Şu an eğitim-öğretim çağında bulunan nesil, $Z$ kuşağı olarak tanımlanmaktadır. Bu kuşak kaynaklarda tanımlanan diğer kuşaklardan daha keskin sınırlarla ayrılmaktadır (Adıgüzel, Batur ve Ekşili, 2014). Bilgisayarı ve dijital teknolojiyi farklı amaçlarla çok yoğun olarak kullanan $Z$ kuşağı çocukları, metinleri yüz yüze konuşmaya, bilgisayardan okumayı ve araştırmayı da kitaplardan okuma ve araştırmaya tercih etmektedirler. Teknolojisiz bir yaşam düşünemeyen bu kuşağın bireyleri yüzyüze iletişim yerine çevrimiçi iletişim kurmayı tercih etmektedirler. (Avcı ve Er, 2018; Taş, Demirdöğmez ve Küçükoğlu, 2017; Ünüsan Atak, 2016). İlgili alanyazında “İnternet Kuşağ1" ya da "İ- Nesli" olarak da tanımlanan Z kuşağı çocukları işbirliğine yatkın, yaratıcı, amaç odaklı, esnekliğe önem veren ve uluslararası fırsatları kovalamak isteyen özellikleri ile ön plana çıkmaktadır (Çetin ve Karalar, 2016; Seymen, 2017; Vogel, 2015). Bu noktada eğitimcilerin değişim içindeki bu kuşağ1 anlayıp analiz ederek eğitim öğretim sürecini bu kuşağın sergilediği özelliklere göre yönetmesi ve bu özelliklerinden yola çıkarak öğrencilerine kılavuzluk etmesi başarılı bir gelecek için büyük önem taşımaktadır. Z kuşağının beklenti ve ihtiyaçlarının, klasik sınıflarda sıra düzeninde oturan ve bilgi kaynağını sadece öğretmen olarak gören daha önceki kuşaklardan farklı olduğunun bilincine varılması ve eğitimde etkili dönüşümler yapılması günümüzde bir gerekliliktir. Bu noktada eTwinning platformu yeni neslin ihtiyaçlarına ve beklentilerine göre oluşturulan yenilikçi projeler ve ortaya çıan kavramlar ile dikkatlerini çekmeye devam etmektedir. Öte yandan öğretmenlerin ulus ötesi platformlarda yeterliliklerinin artması ve işbirlikleri kurabilmesi; bilgi gücüne değil hayal gücüne dayalı öğrencilerin yetişmesinde, çok dilli çok kültürlü yapıya doğru ilerleyen küresel eğitim dünyasında söz sahibi olmalarında etkili olacaktır. Ulusal ve uluslararası özellikte ki projeler ile eTwinning öğretmenleri, kazandıkları küresel öğrenme ve öğretme tecrübeleri ile kendilerini yenileyerek daha başarılı bir neslin yetişmesine önemli derecede katkı sağlayabileceklerdir (Altun ve Sel, 2018; Yaylac1, 2013; www. etwinning.net, 2019).

$\mathrm{Bu}$ araştırmanın temel amacı, eTwinning platformuna ilişkin olarak platformun kullanıcıları olan öğretmenlerin görüş ve değerlendirmelerini belirlemek ve aynı zamanda platformun kullanımına yönelik öneriler geliştirmektir. Araştırmada bu temel amaç çerçevesinde aşağıdaki sorulara yanıt aranmaktadır; 
1. Öğretmenlerin eTwinning platformunun kullanılabilirliğine yönelik görüşleri nelerdir?

2. Öğretmenlerin eTwinning platformunun mesleki gelişimlerine katkıları konusundaki görüşleri nelerdir?

3. Ö̈̆gretmenlerin eTwinning platformuna yönelik önerileri nelerdir?

\section{Yöntem}

$\mathrm{Bu}$ araştırma nitel bir durum çalışmasıdır. Durum çalışmalarında amaç bir durum hakkında detaylı betimlemeler yaparak durumu var olduğu şekilde anlamak, bir durum ile ilgili ayrıntılı bilgi edinmek, bazen de kuramın doğruluğunu ve bağlama göre etkinliğini açıklamak olarak tanımlanmaktadır (Saban ve Ersoy, 2017). Durum çalışmalarında bir veya birden fazla olay, ortam, program veya birbirine bağlı sistemler derinlemesine incelenir (McMillan, 2000). Alışık olmayan durumların derinlemesine incelenmesini sağlaması ve okuyucuya kendi bulunduğu durumla sunulan durum arasında karşılaştırma yapma fırsatını sağlaması durum çalışmalarının önemli avantajlarındandır (Gall, Borg ve Gall, 1996). Bu araştırmada ele alınan durum ise "eTwinning platformunun kullanım" durumudur.

\section{Katılımcılar}

Araştırmanın katılımcı grubunu, okul öncesi eğitimi öğretmenliği ve sınıf öğretmenliği branşlarından toplamda 20 öğretmen oluşturmaktadır. Araştırmada katılımcıların belirlenmesinde amaçlı örnekleme yöntemlerinden ölçüt örnekleme yöntemi kullanılmıştır. Ölçüt örnekleme yöntemindeki temel anlayış önceden belirlenmiş bir dizi ölçütü karşılayan katılımcıların araştırmaya dâhil edilmesidir (Yıldırım ve Şimşek, 2013). $\mathrm{Bu}$ araştırmada da temel ölçüt araştırma kapsamında yer alan tüm katılımcıların eTwinning portalına üye olmaları burada geliştirilen proje ve eğitim faaliyetlerine aktif olarak katılmış olmalarıdır. Tablo 1'de araştırmanın katılımcısı olan öğretmenlerin demografik niteliklerine ilişkin bulgular yer almaktadır.

Araştırmanın katılımcıları cinsiyet, yaş, öğrenim durumu, çalışılan kurumun türü, branş, mesleki deneyim süresi açısından da değerlendirilmiştir. Cinsiyetleri açısından, \% 70'i kadın ( $\mathrm{f}=14)$, dolayısıyla \% 30' u erkektir $(\mathrm{f}=6)$. Yaşları bakımından katılımcıların \% 15' $\mathrm{i}$ $(\mathrm{f}=3)$ "21-30 yaş”, \%65'i (f=13) "31-40 yaş", \%15'i (f=3) "41-50 yaş" ve “50 ve üzeri”, \%5' $\mathrm{i}$ $(\mathrm{f}=1)$ yaşlarındadırlar. Öğrenim durumlarına göre ise, katılımcı öğretmenlerin \%90'1 $(\mathrm{f}=18)$ “lisans", \% 10 'u (f=2) yüksek lisans öğrenim düzeylerine sahiptir. Katılımciların \%15' $\mathrm{i}$ $(\mathrm{f}=3)$ "1-5 y1l”, \% 25'i (f=5) “6-10 y1l”, \%50'si (f=10) “11-15 y1l”, \%10'u (f=2) “15 y1l ve üzeri” mesleki deneyim süresine sahiptirler. Tüm bu bilgilere göre, araştırmada en çok kadın katılımcılar yer almakla birlikte, katılımcıların daha çok "21-30 yaş” grubunda yer aldığ1 ve öğrenim açısından da en çok "Lisans" grubunda, kurum türü açısından devlet okullarında görev yaptıkları, mesleki deneyim süresi açısından "11-15 yıl” branş açısından ise okul öncesi eğitimi ve sınıf eğitimi öğretmenlerinin eşit sayıda katılım sağladıkları görülmektedir. 
Tablo 1

Katılımoların demografik niteliklerine ilişkin bulgular

\begin{tabular}{|c|c|c|}
\hline Değişkenler & Demografik Özellikler & Frekans (f) \\
\hline \multirow[t]{3}{*}{ Cinsiyet } & Kadın & 14 \\
\hline & Erkek & 6 \\
\hline & Toplam & 20 \\
\hline \multirow[t]{5}{*}{ Yaş } & 21-30 yaş & 3 \\
\hline & $31-40$ yaş & 13 \\
\hline & $41-50$ yaş & 3 \\
\hline & 50 yaş ve üzeri & 1 \\
\hline & Toplam & 20 \\
\hline \multirow[t]{5}{*}{ Öğrenim Durumu } & Önlisans & - \\
\hline & Lisans & 18 \\
\hline & Yüsek lisans & 2 \\
\hline & Doktora & - \\
\hline & Toplam & 20 \\
\hline \multirow[t]{3}{*}{ Çalışılan Kurumun Türü } & Özel & 1 \\
\hline & Devlet & 19 \\
\hline & Toplam & 20 \\
\hline \multirow[t]{3}{*}{ Branş } & Okul öncesi eğitimi öğretmeni & 10 \\
\hline & Sınıf öğretmeni & 10 \\
\hline & Toplam & 20 \\
\hline \multirow[t]{5}{*}{ Mesleki Deneyim Süresi } & $1-5$ y1l & 3 \\
\hline & $6-10$ yil & 5 \\
\hline & $11-15$ y1l & 10 \\
\hline & 15 yıl ve üzeri & 2 \\
\hline & Toplam & 20 \\
\hline
\end{tabular}

\section{Veri Toplama Arac1}

Araştırmada öncelikle nitel araştırmalarda veri toplamada görüşme tekniğine ilişkin alan yazın taramasına gidilmiş (Baltacı, 2019; Saban ve Ersoy, 2017; Yıldırım ve Şimşek, 2013), ardından araştırmacı tarafından, veri toplama aracı olarak kullanılan yarı yapılandırılmış görüşme formu oluşturulmuştur. Hazırlanan bu görüşme formu nitel araştırma alanında bir uzmanın görüşüne sunulmuş ve uzmandan gelen dönüt ile birlikte forma son şekli verilmiştir. Araştırma öncesinde katılımcılar etik konular hakkında bilgilendirilmiş, gönüllük esasına bağlı olarak görüşmeler gerçekleştirilmiştir. Görüşmelerin çoğunluğu yüz yüze ve okul ortamından bağımsız olarak yapılırken, farklı illerde görev yapan öğretmenler ile de çevrimiçi görüşmeler şeklinde yapılmıştır. Araştırma kapsamında gerçekleştirilen görüşmelerde katılımcı öğretmenlerin branş, çalıştıkları okul türü, mesleki kıdem, yaş gibi demografik bilgileri alınmış, eTwinning portalına üye oldukları süre, katıldıkları proje sayısı, kurucusu oldukları proje sayısı, kalite etiketi değişkenleri hakkında veri toplanmış ardından, araştırmanın da konusunu oluşturan eTwinning platformu ile ilgili derinlemesine görüşleri ve değerlendirmeleri alınmıştır. Araştırmanın veri toplama süreci; 2018-2019 öğretim yılının ikinci döneminde, Mayıs-Haziran 2019 tarihleri arasında gerçekleştirilmiştir.

Lincoln ve Guba (1985), nitel araştırmalarda geçerlik ve güvenirliğin inandırıcılık, aktarılabilirlik, tutarlılık ve teyit edilebilirliğin uygulanmasıyla gerçekleşeceğini 
belirtmişlerdir. Araştırmada inandırıcılığı artırabilmek için katılımcı özelliklerinin detaylı olarak verilmesine ve betimlemeler yapılmasına dikkat edilmiştir. Yanı sıra veri toplama sürecinin sonunda katılımcı teyidine başvurulmuş, aktarılabilirlik için ise doğrudan alıntılara yer verilmiş ve anlaşılır bir dil kullanılmasına dikkat edilmiştir. Araştırmada araştırma süreci ve bulgular detaylı şekilde ve tablolaştırılarak yansıtılmıştır. Katılımcıların görüşleri doğrudan yapılan alıntılarla sunulmuştur. Araştırmada güvenirliliğin sağlanması için yarı yapılandırılmış görüşme sorularının hazırlanmasında ve görüşmeler sonucu elde edilen verilerin analizinde uzman görüşüne başvurulmuştur. Ayrıca etik kurallara dikkat edilmiş, katılımcıların görüşmelerden önce araştırmanın amaçları ve araştırma sürecine yönelik bilgilendirme yapılmış ve gönüllü katılımın sağlanmasına özen gösterilmiştir.

\section{Verilerin Analizi}

Araştırmada verilerin analizinde betimsel analiz yöntemine başvurulmuştur. Araştırmada katılımcı öğretmenlerden, yarı yapılandırılmış görüşme yoluyla toplanılan nitel veriler, betimsel analiz tekniği kullanılarak çözümlenmiş ve yorumlanmıştır. Bu süreçte, görüşme ses kayıtları, görüşmede tutulan notlar ayrıntılı olarak analiz edilmiş, temalaştırma ve kodlama yoluyla sistematize edilerek, yorumlanmış ve değerlendirilmiştir. Etik nedenlerle, araştırma verilerinin çözümlenmesi ve raporlaştırma sürecinde, katılımcı öğretmenlerin görüşleri (Ö1, Ö2, Ö3) kodlarıyla eklenmiştir.

Nitel araştırmalarda, veri analizi kımında elde edilen verilerin betimlenmesi, açıklanması ve temalaştırılması ve yorumlanması söz konusudur. Betimsel analiz yoluyla analiz edilen veriler araştırma soruları ile uyumlu temalar çerçevesinde düzenlenip yorumlanmıştır. Raporlaştırma kısmında ise olgunun kavramlar ve temalar çerçevesinde tanımlanması, doğrudan alıntılar yapılması olağandır ve araştırmada da doğrudan alıntılara yer verilmiştir (Yıldırım ve Şimşek, 2013).

\section{Bulgular}

Araştırma verileri araştırma sorularına uygun olarak temalandırılarak analiz edilmiştir ve bu temalar da 3 başlik altında incelenmiştir.

\section{Öğretmenlerin e twinning Platformunun Kullanılabilirliğine Yönelik Görüşleri}

Araştırmada yarı yapılandırılmış görüşmeler iki bölümden oluşmaktadır. İlk bölümde katılımcı öğretmenlerden hem demografik veriler, hem de e Twinning üyelik bilgileri ve katıldıkları projeler konusunda bilgi alınmış, bu bilgiler bir frekans tablosuna dönüştürülmüştür. Görüşmenin ikinci bölümünde ise eTwinning platformunun kullanılabilirliğine yönelik bilgiler ve öneriler alınmıştır. Görüşmelerinde ilk bölümünden elde edilen veriler ile Tablo 2 'de sunulan katılımcı öğretmenlerin eTwinning kullanımlarına ilişkin bilgilere ulaşılmıştır. 
Tablo 2

Katılımcıların eTwinning kullanımlarına ilişkin bilgileri

\begin{tabular}{|c|c|c|}
\hline Değişkenler & & Frekans(f) \\
\hline \multirow[t]{5}{*}{ eTwinning Üyeliği } & $0-6$ ay & 7 \\
\hline & $1 \mathrm{y} 1 \mathrm{l}$ & 4 \\
\hline & 2y1l & 5 \\
\hline & 3 y1l & 1 \\
\hline & 4 yıl ve üzeri & 3 \\
\hline \multirow[t]{2}{*}{ Proje kuruculuğu } & Yaptım & 10 \\
\hline & Yapmadım & 10 \\
\hline \multirow[t]{8}{*}{ Ortaklık yapılan proje sayısı } & Ö6, Ö8, Ö17, Ö18, & 1 \\
\hline & Ö2, Ö12, Ö13, Ö9 & 2 \\
\hline & Ö14, Ö19 & 3 \\
\hline & Ö20, Ö15 & 4 \\
\hline & Ö10, Ö11 & 10 \\
\hline & Ö7 & 13 \\
\hline & Ö1 & 22 \\
\hline & & 25 \\
\hline \multirow[t]{2}{*}{ Kalite etiketi } & Aldım & 5 \\
\hline & Almadim & 15 \\
\hline Toplam katılımcı sayısı & & 20 \\
\hline
\end{tabular}

Araştırmanın katılımcıları olan öğretmenlerin çoğu (f=7) eTwinning'e yeni üye olmuşlar ve ilk projelerini uygulamışlardır. eTwinning projeleri süre ve ortak sayısı açısından esnek olabilmektedir. Bazı projeler birkaç ay sürerken, bazıları bir eğitimöğretim yılı boyunca sürebilmektedir. Yine yüzlerce ortağı olan projeler olduğu gibi az sayıda ortakla da yürütülen projeler görülmektedir. Öğretmenler öğrencilerinin velilerinden aldıkları resmi izin ile ve bilgilendirme toplantılarından sonra öğrencileriyle birlikte birden fazla projeye ortak olabilmektedirler. Öğretmenler proje desenleyerek kurucu rolü üstlenip, ulusal ya da uluslararası projeler üretebilmekte farklı ülkeler ve farklı okullardan ortaklıklar yaparak projelerini yürütebilmekte, projelerinin sonuçlarını kendi geliştirdikleri araçlar çerçevesinde ortaya koyabilmektedirler. Araştırmada katılımcı öğretmenlerin yarısı proje kuruculuğu da yapmaktadır. eTwinning'e üye olan bir öğretmen doğrudan kendi projeleriyle de platformda aktif olarak, kuruculuk sorumluluğunu üstlenip benzer fikirlere sahip aynı zamanda proje konusunda kendini ve öğrencilerini geliştirmek isteyen meslektaşlarını bir araya getirme misyonunu yüklenebilmektedir. Ortak olunan projelerin bitiminde ya da bitme aşamasına girildiğinde ise her ülkenin ulusal destek servisinin açıklamış olduğu tarihlerde sistem üzerinden "Kalite Etiketi Ödülü" başvurusu yapılarak, projenin belli kriterler ölçüsünde değerlendirmeden geçirilmesiyle kalite etiketi ile ödüllendirilmesi mümkün olmaktadır. Öte yandan projenin ödüllendirilmesinin ardından projenin yürütüldüğü okullarda "eTwinning Okul Etiketi" alabilmektedirler. Böylelikle eTwinning faaliyetlerine daha geniş bir yelpazede katılımın sağlanması, aynı okuldaki öğretmenlerin mesleki gelişim 
faaliyetlerine katılımları, diğer okullardaki meslektaşlar ile işbirliği yapılması, eTwinning tanıtım faaliyetleri ile ebeveynlerin, diğer okulların ve kuruluşların bilgilendirilmesi amaçlanmaktadır. eTwinning Okulu etiketi, eTwinning'in dört ana alanına katkısını yansitmaktadir;

- Okulda eSafety (elektronik güvenlik) farkındalığı geliştirmek,

- Yenilikçi öğretme ve öğrenme uygulamaları, disiplinler arası öğretim ve proje uygulamaları,

- Öğretmenler ve diğer eğitim personeli için mesleki gelişim,

- Okulun stratejik gelişiminin sağlanmasıdır (Full Report, 2017).

Katılımcı öğretmenlerden Ö13, platforma dair görüşleri şöyledir; “eTwinning platformu kişisel gelişimi destekleyen, aynı anda yüzlerce, binlerce üyeyi hiçbir karışıklığa sebebiyet vermeden bir arada tutan, üyeler arasında video, fotoğraf, yazı vb. yollarla bilgi alışverişini sağlayan, projeler kurularak uygulama sürecinde diğer ülkelerdeki meslektaşlarımıza ulaşılmasını kolaylaştıran bir platformdur." Bir diğer katılımcı Ö14 ise platformu şu şekilde tanımlamıştır; "İletişim ve işbirliğinin olduğu, projelerin geliştirilip paylaşıldığı, hareketli ve eğlenceli bir öğrenme topluluğudur. Çevrimiçi mesleki gelişim imkanlarını eğitimcilere ücretsiz sunar. Öğretmenler, eTwinning'in Avrupa düzeyinde sunduğu çevrimiçi mesleki gelişim fırsatlarını bulurlar."

Tablo 3

eTwinning platformunun kullanılabilirliğine yönelik bulgular

\begin{tabular}{lc}
\hline Kodlar & Frekans (f) \\
\hline Paylaşımlarda yaşanan sorunlar (fotoğraf ve video yükleme vb.) & 8 \\
Kullanımı kolaydır & 5 \\
Kullanışlı değil & 5 \\
Platformun işleyişini anlamakta zorlandım & 5 \\
Zengin bir bilgi ortamı sunmaktadır & 3 \\
Dil sorunu yaşıyorum & 3 \\
Eğitimde fırsat eşitliğini arttırmaktadır & 2 \\
Webinarlara girişte ve sürdürülmesinde sorunlar çıkmaktadır & 2 \\
Toplam Katılımcı Sayısı & $\mathbf{2 0}$ \\
\hline
\end{tabular}

eTwinnning kullanıcılarına eğitsel paylaşımlar yapma, diğer öğretmenler ile işbirlikli olarak etkinlikler oluşturma ve oluşturulan bu etkinliklerin sinıflarda uygulanması sırasında çekilen görsellerin e-güvenlik kurallarına dikkat edilerek paylaşılmasına imkan vermektedir. Tablo 3 incelendiğinde, öğretmenlerin eTwinning'i kullanırken paylaşımlarda sorun yaşadıkları bulgusuna ulaşılmaktadır. Öğretmenler; "İletişim konusunda platform kullanışlı değil, her ne kadar 28 dile çevrilse de iletişim de sorun yaşıyorum (Ö4)", "Sisteme yükleme yapmak, projeler için paylaşımlar yapmak bazen zorlayıcı olabiliyor (Ö6)", "Video paylaşımlarım direkt yapamadığım için zorlanıyorum. Youtube gibi platformlardan link ile paylaşmaktansa direkt paylaşabilmeliyim diye düşünüyorum (Ö7)", "Çok hâkim değilim. Yeni keşfediyorum. Ancak katıldı̆̆ım anda çok sevdim. Paylaşım yapmada zorlandım (Ö8)", "Beni en çok zorlayan kısmı okulda yükleme yapamadığım için evde vakit ayırmam gerekiyor (Ö16)", "Bazen yükleme yapmakta zorlanıyorum. Değişik teknolojik uygulamalarn kullanmak durumunda kalabiliyorum bu anlamda Ingilizceyi çok iyi anlayamamam beni zorluyor. Aslında e Twinning'in çok fazla zorlayan bir yanı yok (Ö9)", 'En çok zorlandiğım bölüm yabancı ortaklarla iletişim (Ö10)" şeklinde görüşler bildirmişlerdir. Öğretmenler 
görüşlerinde platformun kullanışlı olmadı̆̆ı, proje faaliyetlerinin eğitim sürecinde uygulanmasının ardından yapılması gereken paylaşımların (video, fotoğraf vb. ürünler) platforma yüklenmesinde ve yabancı ortaklar ile iletişim konusunda sorun yaşadıklarını belirtmişlerdir. Ö11 ise:

“Çalışmalar ile ilgili sorulan sorulara bir türlü cevap verilmemesi, sistem kullanımıyla ilgili açıklama ve uyarıların gereksiz zamanda yapılması, proje ödül başvurularında öğretmenleri bu sistemden soğutacak derecede detaylı, anlaşılması güç ve ağır içerikli taleplerde bulunulması sorun yaratıyor. Oysa proje yapılmış, her şey ortaya konulmuş. Görülenin, yapılanın sorgulanması hakikaten tuhaf bir anlayış."

Ö11'in görüşleri incelendiğinde, Türkiye Ulusal Destek Servisi'nce bazı konularda yeterli açıklamalarda bulunulmaması ve bu durumunda belirsizlikler yaratması nedeniyle proje bitiminde yapılan kalite ödülü başvurularında zorlandığı ve öğretmenin sorun yaşadığı anlaşılmaktadır.

Öte yandan katılımcı öğretmenler eTwinning'in kullanıcılarına fırsat eşitliği sağladığı, farklı sosyoekonomik koşullar, gelişmişlik düzeyi, dil ve kültürlerden gelen öğretmen ve öğrencileri buluşturarak birlikte projeler kurmasını, paylaşımlar yapmalarını sağladığ1 konusuna değinmişlerdir. Bu bağlamda Ö2 ve Ö5; "Okullar arası öğrenci paylaşımları, sosyallikleri arttı. Ülkenin gelişmişlik düzeyi, sosyoekonomik durumu ne olursa olsun firsat eşitliği artması gibi açılardan yararlı görüyorum (Ö2)", "Bunun firsat eşitliği adına önemli bir adım olduğunu düşünüyorum. eTwinning platformunun işleyişini anlayabilmek ilk etapta biraz zor geldi. Sonra zamanla alıştım (Ö5)"şeklinde görüşlerini ifade etmişlerdir.

Katılımcı öğretmenlerden eTwinning platformunu kullanmakta zorlananlar ya da pratik olmadığını düşünenler olduğu gibi, aksini düşünenlerde bulunmaktadır; $\mathrm{Bu}$ bağlamda; "Arkadaşlarım çok destek oldu, ne nasıl yapılır sürekli anlattılar, çok zorlanmadan büyük bir ilerleme kaydettim (Ö12)", "Platformun beni zorladığı bir kısım olmamıştır. Son derece pratik ve kullanışlıdır (Ö13)", "Güvenli kullanıcı dostu anlaşılır bir platform (Ö15)" cümleleri ile görüşlerini açıklamışlardır.

Ö17 ve Ö20 kodlu öğretmenler de yapılan güncellemeler ile değişen sayfa yapısının kullanımlarını zorlaştırdığını ifade etmişlerdir;"Daha önceki ara yüz böyle değildi ancak yeni ara yüzde sayfanın silinmesi çok kolay bu sebeple dikkatli çalışmayan öğretmenler sayfaları silebiliyor. Tekrar tekrar yükleme yapmaktan çok yoruldum (Ö17)", "Eski ara yüzde farklı Web araçların rahatlıkla kullanabiliyorduk ancak yeni ara yüz çok yetersiz (Ö20)”. Ö14 ise karş1laştığ1 diğer önemli sorunlara değinmiştir;

Okul internetinde bazı yapmak istediklerimize yasal sınır olması (webinar gibi), bazı projelerde işleyişte planın dışına çok fazla çıkılması ve öğretim programıyla uyuşmayan ekstra etkinliklerin eklenmesi, okul dışında da fazla zaman alması, bazı velilerin projelere izin dilekçesini vermemesi yüzünden o çocukların etkinliklerde ayrı kalması, okul idaresinin tutumu, maddi olarak harcamaları öğretmenin kendisinin yapması projelerin uygulanmasını zorlaştırıyor açıkçası.

Yukarıdaki görüş incelendiğinde Ö14'ün okullarda proje kapsamında gerçekleştirilen webinarlara katılımlarının sorun yaratması, bazı projelerde önceden yazılan proje planının dışına çıkılarak proje ortaklarını artan iş yükü ile zorlanması, projenin amaçları ile uygulanan öğretim programının örtüşmemesi, velilerin proje faaliyetlerine önyargılı bakarak öğrencilerinin katılımlarına izin vermemesi, okul yönetiminin projelerin uygulanma sürecinde öğretmene yeterince destek vermemesi daha açık bir ifadeyle projelerin uygulanma aşamasında proje faaliyetleri için gereken maddi desteği alınamaması ve ortaya çıkan mali yük nedeniyle projeleri uygulama sürecinde zorlandığı anlaşılmaktadır. 


\section{Öğretmenlerin eTwinning Platformunun Mesleki Gelişimlerine Katkıları Konusundaki Görüşleri}

Araştırmanın ikinci alt problemine ilişkin öğretmenlere “'eTwinning platformunun mesleki gelişiminize katkıları nasıldır? Açıklayınız.'” Sorusu sorulmuş, verilen cevaplardan elde edilen verilerin analizi sonucunda toplamda $12 \mathrm{kod}$ belirlenmiştir.

Tablo 3

Öğretmenlerin eTwinning platformunun mesleki gelişimlerine katkılarnna yönelik bulgular.

\begin{tabular}{lc}
\hline Kodlar & Frekans (f) \\
Meslektaşlar ile işbirliği yapabilme & 13 \\
Meslektaşlardan yeni yaklaşım ve yöntemlerin öğrenilmesi & 12 \\
Web 2 araçlarını öğrenilmesi & 12 \\
Motivasyonda artış oluşturması & 10 \\
Meslektaşlar ile iletişimi sağlaması & 9 \\
Mesleki doyumda artışı sağlaması & 9 \\
Teknoloji kullanımının gelişimi & 8 \\
Online eğitimler ile mesleki gelişimi sağlaması & 7 \\
Proje odaklı mesleki gelişimi sağlaması & 7 \\
Yenilikçilik ve yaratıcılı becerisinin gelişimi & 6 \\
Özgüven gelişimini sağlaması & 5 \\
Yabancı dil gelişimini sağlaması & 3 \\
Toplam Katılımcı Sayısı & $\mathbf{2 0}$ \\
\hline
\end{tabular}

Tablo 3 incelendiğinde, "meslektaşlar ile işbirliği yapabilmek" ( $f=13)$, en yüksek frekansa sahip kod olarak görülmektedir. Bu kodu "Meslektaşlardan yeni yaklaşım ve yöntemlerin öğrenilmesi" (f=12) takip etmektedir ve yine "Web 2 araçlarının öğrenilmesi" kodu da $(\mathrm{f}=12)$ eşit frekans ile takip ettiği görülmektedir. Katılımcı öğretmenler "meslektaşları ile işbirliği yapabilmek" kodu ile ilişkili olarak; "Bu alan büyük bir ögretmenler odası gibi. Kendini sürekli geliştirmeye çalışan, araştıran, sorgulayan, paylaşan, üreten ve en önemlisi gönüllü öğretmenlerden oluşan bir platform. Platformda ki birçok kişi ile etkileşime geçip monoton mesleki çevremi genişlettim. Okulca katıldığımız projelerde paylaşımlarımız arttı (Ö2)", "Farkl coğrafyadan aynı fikirleri çok çeşitli olarak yorumlayarak başka bakış açıları geliştirmeye yardımcı olmaktadır (Ö4)" cümleleri ile görüşlerini açıklamışlardır. Bu konuda daha detaylı bir görüş bildiren Ö1 ise;

“Yeni yaklaşımları öğrenmek, farklı ülke ve okullardaki öğretmenlerle çalışmak, iletişim kurmak, paylaşımlarda bulunabilmek mesleki gelişimim açısından oldukça yararlı. Proje doğrultusunda iş birliği yaparak aynı hedef için çalışarak başarmak, mesleki açıdan doyuma ulaşmamı sağlıyor. Uygulanan yeni yaklaşım ve metotlar heyecanımı artırıp motivasyonumu sağllyor. Öğrenme etkinlikleri, kurslar, çevrimiçi seminerlerin bana katkısı büyük. Farklı ülke ve okullardan öğretmen arkadaşlarımızla iletişim, paylaşım ve çalışma fırsatı sağlıyor. Ve açıkçası kendimizi daha iyi tanıma, birlikte elde ettiğimiz başarılarımız ile özgüven kazanmamızı sağlayarak, kişisel gelişimimiz ve yeni başarılarımız için ortam hazırlıyor."

Ö1'in görüşlerinden aynı projede farklı ülkelerden farklı öğretmenler ile işbirliği yapabiliyor olmasının kendisinin motivasyonunu arttırdığ 1 ve hem kişisel hem de mesleki anlamda gelişim sağlamasında etkili olduğu anlaşılmaktadır. Katılımcı öğretmen Ö3 ise farklı koşullara sahip okulların birlikteliğine değinerek, aslında eTwinning' in çok önemli bir işlevine de değinmiştir; "Mesleki açıdan farklı kültürlerde benzer yaş gruplarıla ortak bir etkinlik çıkarabilmek, şartlar kötü olsa bile ortak bir paydada buluşturma imkânı sağlaması çok güzel. Okul öncesi öğretmen ile tanışarak yaratıcılı̆̆ımın gelişmesi, yenilikler ile tanışmamı 
sağlaması, iletişim ve etkileşimimin artması çok güzel gelişmeler benim için". Ayrıca öğretmenler görüşlerinde eTwinning platformunun mesleki gelişimlerini doğrudan etkileyen yenilik, yaratıcılık becerilerinin gelişimindeki faydalarına da değinmişlerdir. Katılımcı Ö5 bu anlamda görüşlerini şu cümleleri ile açıklamıştır;

“Uluslararası projelerde yer almak oldukça heyecan verici. Birçok meslektaşımızla tanışma, paylaşma, yardımlaşma imkânı buluyoruz. Birbirimizden öğrendiğimiz çeşitli web2 araçlarını, edindiğimiz bilgileri öğrencilerimizle uygulama imkânı buluyoruz. Bir sonuca ulaşmak, emeklerimizin karşılığını almak, hem bize mesleki doyum kazandırdı hem de buna bağlı olarak özgüven oluşumunu destekledi. Kendimizi yeniliyoruz, güncelliyoruz ve daha yaratıcı oluyoruz."

Katılımcı öğretmenler eTwinning ile eğitim alanında gelişen yeni yaklaşımlar konusunda da kendini geliştirebildiklerini ifade etmişlerdir. Öğretmen Ö6 bu bağlamda düşüncelerini şöyle belirtmiştir; "Birçok web2 aracını kullanmayı öğrendim, video yapmayı öğrendim. Farklı ögrretmen arkadaşlarımla paylaşımlar yaparak yeni ve farklı şeyler öğrendim. Eğitim adına etkili paylaşımlarımız oldu. Eğitim alanında ortaya çıkan STEM gibi yeni yaklaşımları projeler ile öğrendim", Ö7 ise ülkenin farklı şehirleri ile farklı ülkelerdeki meslektaşlarıyla yaptıkları paylaşımlara şu sözleri ile değinmiştir;

“e-Twinning platformunun öğretmeni geliştirici ve ufuk açıcı olduğunu düşünüyorum. Mesafe kavramını ortadan kaldıran farklı illerdeki ve farklı ülkelerdeki meslektaşlarımızla rahatlıkla iletişim ve paylaşma imkânı sunan bir platformdur. Bunun yanında belirli gün ve haftalar ile ilgili etkinlikler düzenlenmesi yönünden de zengin bir ortamı vardır. Teknolojiyi verimli ve doğru kullanmam konusunda olumlu yönlendirmesi olduğunu düşünüyorum. Derslerimde teknolojiyi daha etkin kullanma konusunda teşvik edici oluyor. Mesleki gelişim konusunda çok fazla katkısı olduğunu düşünüyorum. İlk olarak meslektaşlarımızla fikir alışverişi sağlıyor ve birbirimizden yeni yaklaşımları, eğitim alanında ki gelişmeleri ve uygulamaları görüyoruz. Online toplantılar yapma imkânı iletişimin rahat kurulmasını sağlıyor. Bunun yanında web 2 araçlarının kullanımı konusunda teşvik edici olması derslerimizin daha verimli geçmesini sağlıyor. Meslektaşlarımızla ve öğrencilerimizle projeler, etkinlikler yapma imkânı sunması bizleri zinde ve dinç tutuyor. Farklı ülkelerle paylaşımda bulunmanın önünü açarak öğrenciler açısından ilgi çekici oluyor."

Yukarıdaki görüş incelendiğinde platformun kullanıcısı öğretmenlerin kendilerini günümüzde oldukça önemsenen "Bilgi ve İletişim Teknolojileri” alanında yeterliliklerini arttırdıkları ve eğitim uygulanılan öğretim programı kapsamındaki kazanımlara uygun nitelikte desenlenen proje faaliyetleri ile Web 2.0 araçları kullanılarak teknolojinin etkili ve verimli kullanıldığı öğretme-öğrenme süreçlerinin geliştirilmesini sağladığ1 ayrıca eTwinning projeleri kapsamında farklı ülkeler ile yapılan paylaşımların öğrencilerin de ilgisini çektiği anlaşılmaktadır. Ö13 de eğitimde teknoloji kullanımı noktasına değinmiştir;

“ Benim için en yararlı yönü meslektaşlarımla bilgi alışverişinde bulunarak teknolojiyi aktif bir şekilde kullanmamı sağlamış olmasıdır. Ayını zamanda bilgilerimi sınıf içi etkinliklere yansıtarak mesleki ve kişisel gelişimimin desteklenmesini sağlamıştır. Web 2 araçlarını daha aktif bir şekilde kullanmaya başlamış bulunmaktayım, okulöncesi eğitim programında yer alan etkinliklerdeki çeşitlilik hakkında platformda yer alan aktif kullanıcılar aracılığıyla uygulama farklılıkları hakkında bilgi sahibi olabildim ve kendi öğrencilerimin yaş düzeyime göre etkinlik çeşitliliği sağlayarak uygulayabilme fırsatı bulabildim."

Katılımclların görüşlerinden eTwinning platformunda yürütülen projelerin ve çevrim içi eğitimlerin öğretmenlerin teknolojik yeterliliklerinin gelişmesinde etkili olduğu anlaşılmaktadır. Ö8 ve Ö11 BİT alanında yeniliklere hâkimiyetlerinin artması konusunda aşağıdaki görüşleri paylaşmışlardır;

“Web araçlarını kullanmayı öğrenmeye başladım, teknoloji kullanımım arttı. Öğretmen sürekli çağa ayak uydurmalı ve gelişen teknolojiyi takip etmeli. Çünkü öğrencilerde her geçen yıl yeni donanımlarla geliyor. Bu nedenle mesleki açıdan bana katkısı olduğunu düşünüyorum. 
Derslerimde artırılmış gerçeklik uygulaması gibi yeni yöntemleri kullanmaya başlamam ve doğada ders yapma fikri bana katkılarından sadece ikisi (Ö8)."

"Platform olarak bakıldığında; güzel dostluklara vesile olması itibariyle cazibe oluşturuyor. Özellikle, çalışmalarına okulda yeterli karşılığı bulamayan öğretmenlerin, bir anlamda rahatlama, paylaşma, takdir edilme, önemsenme gibi duyguları yaşamaları nedeniyle tercih ettiklerini düşünüyorum. Bana gelen geri bildirimlerin büyük çoğunluğu bu yönde. Teknolojik yenilikleri takip etmeye neden olması. Bu sisteme giren eğitimciler, istekleriyle eğitimde geliştirilen teknolojik BİT yeniliklerini isteyerek araştırıyor, katılım gösteriyor, öğreniyor ve öğretme yoluna gidiyor (Ö11)."

Eğitim öğretim etkinliklerinin merkezinde yer alan öğretmenlerin farklı konularda geliştirdikleri projeler ile bilgileri ve becerileri artmaktadır. Öte yandan okul yöneticileri ve velilerinden yeterince duygusal destek alamayan öğretmenlerin eTwinning aracılı̆̆ıla tanıştıkları öğretmenlerden duygusal destek aldıkları ve motive oldukları anlaşılmaktadır. Kendileri gibi düşünen öğretmenler ile buluşan katılımcı öğretmenlerin motivasyonlarının arttığı ve yenilikçi eğitim modellerini merak ederek, öğrenmeye çabaladıkları söylenebilir. Ö9 bu durumu şöyle ifade etmiştir;

"eTwinning bana teknolojiyi kullanma -değişik fikirler hakkında sahip olma -istediğim bir etkinliği hayata geçirme-yeni arkadaşlarla tanışma -bana yaptığım meslekten zevk alma uluslararası alanda kendimi anlatma fırsatı sundu. eTwinning' de proje yapmak ve bunu birçok kişiye ulaştığını görmek kendime olan güvenimi arttırıyor. Yaptığım projeler önce müdürüm daha sonra ilçe milli eğitim müdürüm tarafından çok takdir gördü. Bu da benim mesleğime olan inancımı ve heyecanımı arttırdı. Mesleki anlamda çok farklı fikirler, yöntemler öğreniyorum ve hayata geçiriyorum öğrencilerim ve velilerimden gözle görülür şekilde geri dönütler alıyorum öğrencilerime bir şey kazandırdığımı bilmek gurur verici."

eTwinning platformunda Avrupa'dan çeşitli ülkelerdeki meslektaşlarıyla buluşan ve iletişime geçerek ululararası bir mecrada fikirlerini ifade etme olanağı bulan öğretmenlerin aynı zamanda yabancı dil becerilerinde gelişmeler ortaya çıkmaktadır. Katılımcı Ö10 "eTwinning Avrupa okullar arası işbirliği sağlayan, teknolojiyi verimli bir biçimde kullanmamızı sağlayan bir platform. eTwinning kişisel açıdan kendini daha rahat ifade edebilmemi, yabancı dil becerilerimi gelişmeme olanak sağladı. eTwinning mesleki açıdan teknolojiyi en üst düzeyde kullanmamı, yenilikçi ve yaratıcı olmamı să̆ladı." , Ö20 ise düşüncelerini; “Ĕ̆itimin kalitesini artırmak için harika bir platform ve Yeni fikirler edinip ve farkl eğitimler alabiliyoruz. Birçok Web 2 aracı ve öğretim yöntemi öğrendim. Yabancı dil becerileri açısından da çok faydalı oldu." şeklinde ifade etmiştir.

Katılımcı öğretmenler platformun öğretmenlere sunduğu önemli olanaklardan birinin de online kurslar olduğunu belirtmişlerdir. Ö12 bu konuda ki düşüncelerini şu cümleleri ile açıklamıştır; "Harika projeler ile yeni öğretim teknikleri öğrendim, online kurslar ile farklı uygulamalar tanıdım, birçok arkadaş edindim. Çeşitli web2 araçları tanıdım ve bunları derslerde nasıl kullanılır onu öğrendim. Kendimi yeniledim, farklı uygulamalar derslerinde kullanma imkânı buldum, 5 ay zarfinda 35 eğitim aldım."

Yukarıdaki görüşler incelendiğinde, katılımcı öğretmenlerin projeler ile çevrelerinin genişlediğini, çevrim içi eğitimlere katıldıkları ve farklı eğitim olanaklarını da keşfettikleri ve eğitim sürecinde kullandıkları anlaşılmaktadır. Ö14 bu bağlamda şöyle söylemiştir;

“Hem ulusal hem uluslararası projelere girme imkânları sayesinde sosyal çevrem genişledi. Kendime olan güvenim arttı. Mesleki yönden çok olumlu katkıları oldu. Hem yüz yüze hem de çevrimiçi eğitimlere katılma fırsatları buldum. Başka öğretmenlerle iletişimde olmak, işbirliği içinde olmak bilgi paylaşımını artırdığı için mesleki açıdan bildiklerimi geliştirme, bilmediklerimi öğrenme fırsatı buldum. Teknoloji kullanımımı geliştirerek e Twinning projeleri sayesinde web 2.0 araçları ile tanıştım. Web 2.0 araçlarını kullanarak 
öğrencilerime daha farklı etkinlikler hazırlayabiliyorum, eTwinning'e kayıt olduktan sonra www.scientix.eu, www.eun.org gibi farklı eğitim sitelerine kayıt oldum."

Yukarıdaki görüş incelendiğinde öğretmenlerin eTwinning platformunda aktif olmaları ile STEM gibi yenilikçi öğretim modellerini konu alan birbiri ile bağlantılı Scientix vb. Avrupa Birliği kaynaklı çeşitli projelerin eğitim faaliyetlerine erişerek mesleki gelişimlerini devam ettirmektedirler. Katılımcı öğretmen Ö15 ise "Branşım dışında ilgi duyduğum çeşitli alanlarda da ücretsiz çevrim içi eğitim olanaklan ile gelişimimi să̆lama firsatı sunuyor, böylelikle yeni gelişen yöntemler konusunda bilgi sahibi oluyorum. Kendimi yeniliyorum." şeklinde eğitimlerin aynı zamanda ücretsiz oluşuna da vurgu yapmıştır." cümleleri ile görüşünü belirtmiştir.

Öğretmenler kendi planladıkları projeleri de platformda uygulama ve yaygınlaştırma fırsatı bulmaktadırlar, böylelikle proje yazma becerileri ve proje yürütme becerileri de gelişebilmektedir. Ö19 bu bağlamda görüşlerini şöyle ifade etmiştir; "Çok şey öğrendim hem zümrelerimin kullandiğı yeni öğretim yöntemleri, hem web 2 araçları olarak hem de proje yazma ve proje yürütme becerim gelişti. Projelere bakış açım değişti. Online eğitimlerden faydalandım."

\section{Öğretmenlerin eTwinning Platformuna Yönelik Önerileri}

Araştırmanın üçüncü alt problemine ilişkin öğretmenlere "'eTwinning platformunun daha kullanılabilir olması için önerileriniz nelerdir? Açıklayınız.'” sorusu sorulmuş, verilen cevaplardan elde edilen verilerin analizi sonucunda toplamda 7 koda ulaşılmıştır.

Tablo 4

Öğretmenlerin eTwinning platformuna ilişkin önerilerine yönelik bulgular

\begin{tabular}{lc}
\hline Kodlar & Frekans (f) \\
\hline Yaygınlaştırılabilir & 12 \\
Destekleyici hizmet içi eğitimlerin yapılması & 12 \\
Proje yazım süreci ve kalite etiketi hakkında bilgilendirmelerin & 7 \\
arttırılması & 3 \\
Velilerin bilgilendirilmesi & 3 \\
Platformun sosyal ağlar ve EBA ile desteklenmesi & 2 \\
Öğretmenlerin ödüllendirilmesi & 3 \\
eTwinning platformunda alınan çevrim içi eğitimlerin MEBBİS'e & 1 \\
işlenmesi & 20 \\
Toplam Katılımcı Sayısı & $\mathbf{2 0}$ \\
\hline
\end{tabular}

Tablo 4 incelendiğinde, öğretmenlerin eTwinning platformu hakkında pek çok öneri sundukları görülmektedir. Ancak en çok tekrar edilen öneri platformun yaygınlaştırılması önerisidir. eTwinning Türkiye' deki farklı bölgelerdeki öğretmenleri ve yurtdışındaki öğretmenleri birbiri ile buluşturmakta ve öğretmenlerin birbirlerinin uygulamalarını görmeleriyle nitelikli bir öğrenme ortamının oluşmasına olanak sağlamaktadır. Öğretmenler yıllar geçtikçe kendilerini tekrar eder duruma düşmektedir, ancak görebilecekleri farklı bakış açıları onlarında eğitim sürecini zenginleştirmelerinde etkili olabilmektedir. eTwinning platformunun tanıtılması ve yaygınlaştırma çalışmalarının yapılması ile daha fazla öğretmen birbiri ile etkileşime geçmiş olacaktır. Araştırmada katılımcı öğretmenlerden Ö1; "eTwinning yaygınlaştırma çalışmalarına ă̆ırlık verilebilir. Yayginlaştırma faaliyetleri online ve hizmet içi seminerlerle desteklenebilir." şeklinde 
bir öneri ortaya koymuştur. Başarılı projelerin ortaya konulması, bölgesel çalıştayların yapılması eTwinning' in tanıtımı ve yaygınlaştırılmasında etkili olmaktadır.

eTwinning platformu kullanıcısı olan öğretmenlere mesleki gelişim açısından önemli imkanlar sunmaktadır. Öte yandan çeşitli projelerde görevler alan ve bir yandan da çevrim içi kurslar ile daha donanımlı hale gelen öğretmenlerin eTwinning çalışmalarının özlüklerine de yeterince yansıtılmasını istemektedirler. Ö18 bu isteğini şu şekilde ifade etmiştir; "Twinning projelerinde başarll olan projeler kalite etiketi ile ödüllendirilmektedir, bence proje kurucuları ve ortakları mesleki yaşamında da ödüllendirilmesi ve özlüklerimize de işlenmelidir". Katılımcı Ö2 ise bu konudaki düşüncelerini aşağıdaki cümleleri ile açıklamışlardır;

“Öncelikle platform mobil uygulamalarla daha uyumlu olmalıdır (İos ve Android). Yapılan etkinliklerle ilgili bildirimler cebimize anlık olarak gelebilmelidir. Alınan eğitimler ve belgeler "Milli Eğitim Bakanlığı Bilişim Sistemleri" modülüne işlenerek, Mebbis'te e Twinning kariyer sekmesi olup kişinin gelişimi oradan da takip edilmelidir. MEB'de e Twinning ile uğraşan öğretmenlere ilave hizmet puanı verilmesi gibi pozitif ayrımcılık yapılmalı, çünkü projelerin yürütülmesinde ciddi bir gayret sergilenmektedir. Mümkünse kalite etiketi de özlüklerimizde değerli olmalıdır. EBA ile entegrasyonu sağlanabilir. Özellikle Türkçe olması faydalı ama daha sade bir dil benimsenmesi daha iyi olabilir."

eTwinning'e kayıtlı her dört öğretmenden biri Türkiye'den katılmaktadır. Ülkemizden her geçen gün e Twinning'e üye olan öğretmen sayısı artmaktadır. Çeşitli sosyal medya hesaplarında yapılan proje paylaşımları platformun tanınmasını ve yaygınlaşmasını sağlamaktadır. Bu konuda Ö3; "eTwinning'i tanımayan öğretmenlere platformun anlatılması, Bir projede tüm Türkiye'de aynı yaş grupların paydaş yaparak teşvik edilmesi faydalı olacaktır." Ö4 ise; "Bakanlı̆̆ımızca tanıtımı yapılarak yaygınlaşmalıdır." Katılımcı ögrretmenlerden Ö10'da ; "eTwinnig platformunun yaygınlaştırılmasının iyi yapılarak tüm öğretmenlere ulaştırılması, bu sayede öğretmenlerin mesleki olarak gelişmelerini sağlanması gerektiğine inanıyorum. "şeklinde görüşlerini belirtmişlerdir.

Katılımcı öğretmenlerden bazıları da eTwinning kullanımı, projelere ve eğitim faaliyetlerine katılım konusunda yardıma ihtiyaç duymaktadır. Bu kapsamda şu görüşler paylaşılmıştır; "Bu konudaki hizmet içi eğitimlere ă̆ırlık verilmelidir. Öğretmenlere bu faaliyetleri tanıtıcı ve teşvik edici çalışmalar yapılmalıdır." (Ö5), "eTwinning tanıtım toplantıları daha sık yapılabilir 'Proje öncesinde iyi bir proje nasıl olur, kalite etiketi almak için gerekli şartlar nelerdir?' bu konular hakkında bilgilendirmeler yapılabilir."(Ö6), "Uzaktan eğitim olarak değil de seminer döneminde eTwinning kullanma, eTwinning'de proje oluşturma yönetme gibi eğitimler verilmeli bence. Ben daha önce bu platformu oğlumun İngilizce öğretmeninden duymuştum. Ancak bilmediğimden bana kullanması zor gibi gelmişti." (Ö8), "eTwinning'i etkin kullanan arkadaşlarm seminerler düzenleyerek eTwinning hakkında detaylı bilgilendirme yapması, eTwinning'in sosyal ă̆larla desteklenmesi, Her öğretmenin en az bir projeyle eTwinning'e katkı sağlaması konusunda Milli Eğitim Bakanlı̆̆ı'nın çalışma yapmasının gerektiğini düşünüyorum." (Ö9), "Okullarımızda tanıtımının yapılmasının önemli olduğunu düşünüyorum. eTwinning kullanımı ile ilgili en basitten başlayarak hem öğretmenlere hem de projelerin uygulanmasi sürecinde destek vermeleri için velilere eğitimler verilmelidir." (Ö7), "Eğitimler süreklilik arz etmeli. Altı ayda bir yapılan eğitimle, bu sistem öğretilemez. Her gün yeni katılımlarm olduğu bir sistemde, eğitim haftalık olmalı, süreklilik arz etmelidir." (Ö11).

Katılımcı öğretmenler platformu daha verimli olarak kullanabilmek için Milli Eğitim Bakanlığg'nca kendilerine bazı imkanların da sağlanmasını istemektedirler. Bu durumu şöyle ifade etmektedirler; "Okul bütçesinden eTwinning projeleri için bütçe ayrılmal. Öğretmenlere dizüstü bilgisayar ya da tablet verilmeli (telefonlar yüklenen Web 2.0 araçların 
kaldırmayabiliyor)." (Ö14), yükleme ve paylaşımlarda kolaylık sağlanması için ise katılımc1 Ö15; "EBA içerik havuzuyla ortak kullanım alanları olmall, sosyal ă̆lar ile yüklemeler paylaşımlar için daha pratikleştirilebilir." şeklinde çeşitli öneriler sunmuştur.

eTwinning projelerinde hibe olanağı bulunmamaktadır. Dolayısıyla projelerin uygulanma sürecinde tüm giderler projeyi yürüten öğretmenler tarafından karşılanmaktadır. Bu konuda Ö19'un görüşleri şöyledir:

“Telefon uygulamalarında bazı zorlanmalar oluyor. Giderilebilir, iyileştirilebilir. Milli Eğitim Bakanlığı tarafından okullara sağlanan internetten çevrimiçi toplantı yapamıyoruz. Kendi bağlantı imkânlarımızı kullanmak zorunda kalıyoruz. Ayrıca her internet aracını da eTwinning'de kullanamıoruz. Bu projelerin de az bir miktarda da olsa bütçesi olması gerektiğine inanıyorum çünkü özellikle yaygınlaştırma faaliyetleri için kendi bütçemizden harcama yapmak zorunda kalıyoruz. Çoğu okulun parası yok ve öğretmenler kendi ceplerinden harcama yapıyorlar."

eTwining projelerinde odak öğrencilerdir. Öğrenciler için yenilikçi ve yaratıc1 uygulamalar geliştirmek, bu amaca yönelik projeler ve etkinlikler oluşturulması beklenmektedir fakat araştırmada katılımcı öğretmenlerden Ö20 farklı bir konu üzerinde durarak öneriler geliştirmiştir; "Çoğu il temsilcisi ve arkadaşlar zaman zaman yardımcı oluyorlar ama şunu fark ettim görme engellilere yönelik bir çalışma yapılmalı ayrıca velilerinde katılabilmesi onlarla proje yapabilmek isterdim. Sadece öğretmenlerin katıldığı projelerde yapılabilse güzel olurdu."

\section{Tartışma, Sonuç ve Öneriler}

Mesleki gelişim süreci, yaşam boyu öğrenme süreci içerisinde yer almaktadır (Sarıdaş ve Deniz, 2017). Bakanlık tarafından belirlenen mesleki gelişim faaliyetlerinin ise öğretmenlerin gerçek öğrenme ihtiyaçlarını karşılamadığı çeşitli araştırmalarda ifade edilmektedir (Bümen, vd., 2012; Ünver, 2014; Yıldırım, 2016). Öğretmenlerin merkezi ya da yerel eğitimlere çeşitli nedenler ile katılmamaları, yoğunlukları gibi nedenler ile çeşitli çevrim içi eğitim olanağı sunan ortamlarda eğitim alanına yönelik farklı uygulamalar ve gelişmeleri öğrenerek mesleki gelişimlerini sürdürmeleri başarılı bir eğitim süreci ortaya koymalarında önemlidir. eTwinning platformuna ilişkin olarak platformun kullanıcıları olan öğretmenlerin görüş ve değerlendirmelerini belirlemek ve aynı zamanda platformun kullanımına yönelik öneriler geliştirmenin amaçlandığı bu araştırmada katılımcı öğretmenlere yöneltilen eTwinning platformunun kullanılabilirliğinin ortaya konulmasının amaçlandığı ilk görüşme sorusuna verilen cevaplara bakıldı̆̆ında frekansı en yüksek kod, eTwinning platformunda gerek etkinlikler gerekse proje faaliyetlerinin uygulanması sırasında çekilen fotoğrafların paylaşımındaki güçlüktür. Paylaşımlarda resim boyutunun küçültülmesi, videolar da ise doğrudan paylaşım mümkün olmamakta, You Tube gibi sosyal medya araçları vasıtasıyla paylaşım yapılabilmektedir. Bu bağlamda yapılacak bazı değişimler platformu pratikleştirecek, kullanımı kolaylaştıracaktır. Paylaşımlarını gerçekleştiremeyen öğretmenler proje planında açıklandığı şekilde ve zamanında tüm proje faaliyetlerini öğrencileri ile tamamlamış olsalar bile kalite ödülünü alamamaktadırlar. Paylaşımların sorunsuzca yapılması bu anlamda oldukça önemlidir. Yine üçüncü soru olan platformun kullanımına yönelik katılımcı öğretmenler tarafından sunulan önerilere bakıldı̆̆ında, "platformun telefondan kullanımının da desteklenmesi" ifade edilmiştir. Platformun telefondan da kullanılabilmesi her yerde ve her zaman kullanılabilmesini kolaylaştırarak kullanıcı dostu olma özelliğini arttıracaktır.

Ülkemizde uygulanan mesleki gelişim çalışmaları Öğretmen Yetiştirme ve Geliştirme Genel Müdürlüğü tarafından çevrimiçi veya yüz yüze olarak uygulanmaktadır. 
Bu çalışmalara alınan öğretmen sayısı çeşitli nedenlerden dolayı sınırlı tutulmaktadır. Bir milyonu geçen öğretmen sayısı ile Milli Eğitim Bakanlığı' nın hizmet içi eğitimlerden tüm öğretmenlerinin faydalanabilmesi mümkün değildir. Dolayısıyla öğretmenlerin çevrim içi olarak hizmet içi eğitimler almaları yerinde bir çözümdür. eTwinning, kullanıcısı olan öğretmenlere ulusal ve uluslararası düzeyde çevrim içi mesleki gelişim imkanı sunmaktadır, öğretmenler gerek projelerde yer verilen webinarlar yoluyla gerekse portalın sağladığı eğitim uzmanlarının oluşturduğu çevrimiçi eğitimler yoluyla pek çok eğitime ücretsiz olarak erişebilmektedirler (Full Report, 2017; Kearney ve Gras-Velasquez, 2015). eTwinning öğretmenlere ve öğrencilerine 21. yüzyılda oldukça önemli olan öğrenme ve yenilik becerilerinin gelişimi için önemli fırsatlar sunmaktadır. Ancak kullanım sırasında bazı sorunlar yaşanabilmektedir, araştırma sorularına verilen yanıtlardan da anlaşıldığı üzere, eTwinning platformunun kullanımına yönelik öğretmenler tarafından ifade edilen önerilerde okulların internet bağlantısındaki sorunların giderilmesinden bahsedilmiştir. Bozdağ (2017) araştırmasında, projelere rağmen okullarda özellikle internet konusu başta olmak üzere teknolojik alt yapı konusunda iyileştirmelere ihtiyaç duyulduğu sonucuna ulaşmıştır. Ayrıca eTwinning projelerini gönüllü olarak yürüten ve teknolojiyi bu projeler için aktif olarak kullanan öğretmenlerin çabalarının takdir edilmesi ve ödüllendirilmeleri için daha farklı yöntemler geliştirilmesi gerektiği konusuna da değinilmiştir. Benzer ifadeler araştırmanın katılımcısı öğretmenler tarafından da dile getirilmiş, proje yapan öğretmenlerin ödüllendirilmesi ve aldıkları çevrim içi eğitimlerin MEBBİS' e işlenmesi önerilmiştir (Ö2).

Günümüzde toplumların ihtiyaç duyduğu birey nitelikleri değişime uğramaktadır. Teknolojinin etkisiyle sürekli gelişen ve hayatımızın her alanına girmiş olan bilgi karşısında var olan teknolojiyi kullanmak birey için bir ayrıcalık değil adeta zorunluluk haline gelmiştir (Eryılmaz, 2018). Zaman içerisinde internet tabanlı teknolojilerinin yaygınlaşması Web 2.0 teknolojisinin ortaya çıkmasını sağlamıştır. Web 2.0, insanların internet üzerinden paylaşım ortamları içerisinde etkileşim kurarak oluşturdukları sistemi tanımlamaktadır (İşman ve Albayrak, 2014). Bozdağ'ın (2017) yapmış olduğu araştırmanın bulguları aynı zamanda eTwinning gibi ağ temelli öğrenmeyi model alan projelerin okullarda teknoloji entegrasyonun sağlanmasında önemli bir rol oynadığını da ortaya koymaktadır. Günümüz bilgi toplumlarında bireylerin yaratıcı, sorgulayıcı, düşünen ve üreten insanlar olmaları beklenmektedir (Bozkurt, 2014). Dolayısıyla bireylerin sürekli kendini yenilemeleri, geliştirmeleri, farklı platformlarda aktif olarak kendini güncel tutmaları yönünde gayret içerisinde olmaları gerekmektedir. eTwinning'in 10. yıldönümüyle ilgili etkinliklerin bir parçası olarak; 32 ülkeden 6.000 eTwinning öğretmeni, "eTwinning'in katılımcı öğretmenlerin mesleki uygulamalarını ve mesleki gelişimlerini nasıl etkilediğini inceleyen bir anket" çalışmasına katılmışlardır. Anket sonucunda, ankete katılan öğretmenlerin \%90'ından fazlası; takım çalışması, yaratıcılık, problem çözme ve karar verme gibi çapraz becerilerin öğretilmesiyle ilgili becerilerinin eTwinning sayesinde geliştiğini ifade etmişlerdir. Öğretmenlerin \%89'u ise yabanc1 dil eğitimiyle ilgili becerilerinin ve proje bazlı öğretme becerilerinin eTwinning sayesinde geliştiğini belirtti. Öğretmenlerin \%80'i; çok dilli / çok kültürlü bir ortamda eğitim vermeyle ilgili becerilerinin de eTwinning projelerine katılmalarından dolayı geliştiğini ifade etmişlerdir (eTwinning, 2019). Araştırmada da anket sonuçlarını katılımcı öğretmenler eTwinning platformunu kullanımları ile meslektaşları ile işbirliği yapabilme becerilerinde ( $\mathrm{f}=13$ ), meslektaşlarından yeni yaklaşım ve yöntemler öğrenmelerinde $(f=12)$ ve web 2 araçlarını 
kullanarak öğretim sürecini zenginleştirdikleri ve öğrencilerinin de teknoloji kullanımlarını destekledikleri $(\mathfrak{f}=12)$ konusunda görüş bildirmişlerdir. Akran öğrenmesinin üst seviyede olduğu platformda, öğretmenler uzun soluklu projelerin haricinde belirli gün ve haftaları kapsayan ya da Codeweek, Codehours, Outdoor LerningDay gibi uluslararası etkinlikleri kapsayan etkinlikler oluşturabilir, meslektaşlarını oluşturdukları etkinliklere davet ederek, uygulama paylaşımları yapabilmektedirler ve diğer yandan yabancı dil becerilerinin de arttı̆̆ araştırmada ulaşılan bulgular arasındadır. Ayrıca araştırmada ulaşılan demografik verilere bakıldığında; katılımcı öğretmenlerin çoğunluğunun 31-40 yaş arasında oldukları ve 10 yıl ve üzerinde bir süre mesleki deneyime sahip oldukları bulgusuna ulaşılmıştır, bu durumda da katılımcı öğretmenlerin mezuniyetlerinin üzerinden uzun bir süre geçtiği ve eğitim alanında ortaya çıkan gelişmeler konusunda kendilerini yenilemelerinin mesleki anlamda gelişimlerinin sürdürülmesinde etkili olacağı düşünülmektedir.

eTwining'e üye olan öğretmenler projelerini geliştirdikten sonra öğrencilerini de projelerine davet etmektedirler, öğrenciler Twinspace'de bulunan chat gruplarına, tartışmalara katılıp, projeye dair içeriklerini farklı web 2 araçları üzerinden yayınlayabilmektedirler (Bozdağ, 2017). eTwinning öğrencilerin bir 21. yüzyıl becerisi olan dijital okuryazarlık becerilerini artırarak, farklı ülkelerden kendi yaşıtları ile tanışmalarında, farklı uygulamalar görmekte, ufkunu açmaktadır. Öğgrencilerimizi geleceğe hazırlamanın; dinamik bir program, alternatif öğrenme-öğretme ortamları, uluslararası yeterlikler, alternatif yeni uygulamalar, teknoloji ile donanmış bir alt yapı ve kalite ile gerçekleşebileceği (Gelen, 2017) düşünüldüğünde, platformun öğrencileri geleceğe hazırlama noktasında faydalı olacağı görülmektedir. eTwinning platformuna yönelik platformun öğretmen kullanıcılarının görüşleri ve önerileri alınarak araştırmaya yansıtılmıştır. Daha sonra yapılacak araştırmalara da eTwinning platformunun öğrenciler tarafından da değerlendirilmesi görüş ve önerilerinin ortaya konulması oldukça değerli bulgulara ulaşılması bağlamında faydalı olacaktır

\section{Kaynakça}

Adıgüzel, O., H. Z. Batur., ve N. Ekşili. (2014). Kuşakların değişen yüzü ve Y kuşağı ile ortaya çıkan yeni çalışma tarzı: Mobil yakalılar. Süleyman Demirel Üniversitesi Sosyal Bilimler Enstitüsü Dergisi, 1(19), 165-182.

Altun ve Sel (2018). eTwinning okulu başvuru kılavuzu. http:/ / etwinningonline.eba.gov.tr/wpcontent/ uploads/2019/11/eTwinningOkulu-Ba\%C5\%9Fvuru-K\% C4\%B1lavuzu.pdf adresinden erişildi.

Avcı, F., ve Er, H. (2018). Dijital bağımlılığa ilişkin öğretmen görüşlerinin incelenmesi ve çözüm önerileri. Uluslararası Multidisipliner Dijital Bağımlılık Kongresi, 14-16 Kasım 2018. Aydın, Türkiye, Aydın İl Milli Eğitim Müdürlüğü.

Baltacı, A. (2019). Nitel araştırma süreci: Nitel bir araştırma nasıl yapılır? Ahi Evran Üniversitesi Sosyal Bilimler Enstitüsü Dergisi, 5(2), 368-388. https:// doi.org/10.31592/aeusbed.598299

Bozda ğ, Ç. (2017). Almanya ve Türkiye'de okullarda teknoloji entegrasyonu. etwinning örneği üzerine karşılaştırmalı bir inceleme. Ege Eğitim Teknolojileri Dergisi, 1(1), 42-64.

Bümen, T. N., Ateş, A., Çakar, E., Ural, G., ve Acar, V. (2012). Teachers' Professional development in Turkish context: Issues and suggestions. Milli Ĕ̆itim, 194, 31-50. 
Cansoy, R. (2018). Uluslararası çerçevelere göre 21.yüzyıl becerileri ve eğitim sisteminde kazandırılması. Insan ve Toplum Bilimleri Araştırmalan Dergisi, 7 (4), 3112-3134. http:/ / www.itobiad.com/issue/39481/494286 adresinden erişildi. https:// doi.org/10.15869/itobiad.494286

Çetin, C. Karalar, S. (2016). X, Y ve Z kuşağı öğrencilerin çok yönlü ve sınırsız kariyer algıları üzerine bir araştırma. Yönetim Bilimleri Dergisi, 14(28), 157-197.

Erasmus+. (2016). Erasmus+ Program Guide. https://www.etwinning.net/files/EN_eTwinning_Report_2012.pdf adresinden erişildi.

Eryılmaz, S. (2018). Öğrencilerin bilgi ve iletişim teknolojileri yeterliliklerinin belirlenmesi: Gazi Üniversitesi, Turizm Fakültesi örneği. Elektronik Sosyal Bilimler Dergisi, 17 (65), 37-49. DOI: 10.17755/esosder.31098.

https:// doi.org/10.17755/esosder.310987

eTwinning (2019). Measuringtheimpact of eTwinningactivities on teachers' practiceandcompetencedevelopment. https:/ / www.etwinning.net/eunfiles/eTwinning-report-2018-EN.pdf adresinden erişildi.

Full Report (2017). https:/ / www.etwinning.net/eun-files/report2017/ eTwinningreport-2017_DEF.PDF.

Gall, M. D., Borg, W. R., ve Gall, J. P.(1996). Educationalresearch . White Plains, NY: LongmanPublishers USA.

Gelen, İ. (2017). P21-program ve öğretimde 21. yüzyıl beceri çerçeveleri (ABD uygulamaları). Disiplinlerarası Eğitim Araştırmalan Dergisi, 1 (2), 15-29.

Retrievedfromhttp:/ / dergipark.org.tr/jier/issue/33877/348852.

Hadjerrouit, S. (2010). Developing web based learning resources in school education: A user-centered approach. Interdisciplinary Journal Of E-Learning And Learning Object, 6,115-135. https://doi.org/10.28945/1172

Karlı, K. (2013). Dijital bilgelik yolculuğu ve öğrenme yoldaşh̆ğı. İstanbul: LEAD Turkey.

Kearney, C., ve Gras-Velasquez, A. (2015). eTwinning: Ten Years On. Impact on teachers' practice, skills, andprofessionaldevelopmentopportunities, as reportedbyeTwinners. https:/ / www.etwinning.net/eun-files/eTwinningreport_EN.pdf adresinden erişildi.

Kylonen, P. C., ve Bertling, J. P. (2014). Innovative questionnaire assessment methods to increase cross-country comparability. In L. Rutkowski, M. Von Davier, and D. Rutkowski (Eds.), Handbook of international large scale assessment: Background, technical issues, and methods of data analysis (s.277-285). Boca Raton, FL.: CRC Press.

Maden, Cemalettin. (2010). e-Twinning Projesi. http:/ / www.ietc.net/publication_folder/ietc/ietc2011-2.pdf adresinden erişildi.

McMillan, J. H. (2000). Educationalresearch: Fundamentals fortheconsumer. Longman: USA. Partnership for 21st Century Learning (P21). (2007). Framework for 21st century learning. http://www.p21.org/our-work/p21-framework adresinden erişildi.

Pedro, F. (2006). The new millennium learners: Challeng in gour views on ICT and learning. 15 A ğustos 2019 tarihinde http:/ / www.oecd.org/edu/ceri/38358359. pdf adresinden erişildi.

Saban, A., ve Ersoy, A. (2017). Eğitimde nitel araştırma desenleri. Ankara: Anı Yayıncılık 
Sarıdaş, G., ve Deniz, L. (2017). Çevrim içi öğrenme topluluklarının öğretmenlerin mesleki gelişimine etkisine yönelik öğretmen görüşleri. Uluslararası Eğitim Yönetimi Forumu (EYFOR 8), 19 - 21 Ekim 2017.

Sınır-ötesi öğrenme için eTwinning: Yılın okul projeleri ilan edildi (Avrupa Komisyonu, Basin Bildirisi, Temmuz, 2019). https:/ / europa.eu/rapid/press-release_IP-12329_tr.htm. adresinden erişildi.

Sayın, Z., ve Seferoğlu, S. S. (2006). Yeni bir 21. yüzyıl becerisi olarak kodlama eğitimi ve kodlamanın eğitim politikalarına etkisi. Akademik Bilişim 2016, 3-5 Şubat 2016, Adnan Menderes Üniversitesi, Aydın.

Seymen, A. F. (2017). Y ve Z kuşak insanı özelliklerinin Milli Eğitim Bakanlığı 20142019 stratejik programı ve TÜBİTAK vizyon 2023 öngörüleri ile ilişkilendirilmesi. Kent Kültürü ve Yönetimi Hakemli Elektronik Dergi, 10(4), 467-489.

Taş, H. Y.,Demirdöğmez, M., ve Küçükoğlu, M. (2017). Geleceğimiz olan z kuşağının çalışma hayatına muhtemel etkileri. OPUS Uluslararası Toplum Araştırmaları Dergisi, 7(13), 1031-1048. https:/ / doi.org/10.26466/opus.370345

Trilling, B., ve Fadel, C. (2009). 21st century skills: Learning for life in our times. Francisco: Jossey-Bass.

İşman, A., ve Albayrak, E . (2014). Sosyal ağlardan Facebook'un eğitime yönelik etkililiği. Trakya Üniversitesi Eğitim Fakültesi Dergisi, 4 (1), 129-138.

Ünver, G. (2014). Öğretmen eğitiminde kuram ve uygulama arasında bağlantı kurma üzerine bir durum çalışması. Educational Sciences: Theory and Practice, 14(4), 1385-1407.

Vogel, P. (2015). Generation Jobless?: Turning the youth unemployment crisis into opportunity. Hampshire: Palgrave Macmillan.

Yvonna S. Lincoln, Y. S., ve Guba, E.G. (1985). Naturalistic inquıry. London: Sage Publications. https:/ / doi.org/10.1016/0147-1767(85)90062-8

Yaylacı, A. F. (2013). Öğretmenlerin kendini geliştirmelerine ilişkin yaklaşım sorunu. Uşak Üniversitesi Sosyal Bilimler Dergisi, Özel Sayı, 25-40.

Yıldırım, A. ve Şimşek, H. (2013) Sosyal bilimlerde nitel araştırma yöntemleri. Ankara: Seçkin Yayıncılık.

Yildırım, K. (2016). Comparing the views of teachers trained by the different curricula in terms of the effectiveness of university-based teacher training. Elementary Education Online, 15(1), 219-233.

Yılmaz, F.,ve Altun Yılmaz, S. (2012). Çokkültürlülük projesi: e-Twinning uygulamalarına ilişkin öğrenci görüşleri. Dicle Üniversitesi Sosyal Bilimler Enstitüsü Dergisi, 4 (8), 120-132.

Zengin, R., ve Can, T. (2010). Oluşturmacılık kuramı bağlamında çevrimiçi öğretim platformu Moddle'ın öğretmen yetiştirmede kullanımı. Hasan Ali Yücel Ĕğitim Fakültesi Dergisi, 7(2), 55-73.

\section{Summary}

\section{Introduction}

Online learning environments provide individuals with a wide and important opportunity for self-education (Gülbahar, 2017; Zengin \& Can, 2010). Online learning environments also provide teachers and students with a range of new and exciting experiences that are 
not possible in traditional classrooms (Hadjerrouit, 2010). The eTwinning Project was launched as a major product of the e-Learning project at a conference in Brussels in January 2005. eTwinning is an application that supports online-based projects from at least two different European countries and between at least two schools. And Turkey has become a part of this network in 2009. The eTwinning platform provides users with training opportunities through project-based applications. The eTwinning portal offers tools and backing to support the development of teachers and indirectly of students, such as online seminars for teachers. The main purpose of this research is to determine the views and evaluations of teachers who are users of the e-Twinning platform, as well as to develop recommendations. Within the framework of this main purpose, the following questions are sought;

1. What are teachers' views on the availability of the eTwinning platform?

2. What are teachers' views on their contribution to the professional development of the eTwinning platform?

3. What are the teachers' recommendations for the eTwinning platform?

\section{Method}

This research is a qualitative case study. One of the advantages of case studies is that it provides an in-depth analysis of non-familiar situations and provides the reader with the opportunity to make a comparison between his or her present situation and the situation presented (Gall, Borg and Gall, 1996). The case discussed in this research is the use of the eTwinning platform. The participants of the study consisted of 20 teachers from pre-school teaching and primary school teaching branches. In the study, criterion sampling method, one of the purposive sampling methods, was used to identify the participants. The main criterion in this research is that all the participants in the research are members of the eTwinning portal and participated in the projects and training activities developed here. Firstly, a detailed field literature review was conducted and a semi-structured interview form was used by the researcher as a data collection tool. In the research, descriptive analysis method was used for data analysis. Qualitative data collected from the participant teachers through semi-structured interviews which were analyzed and interpreted using descriptive analysis technique.

\section{Results}

The research data were themed and analyzed in accordance with the research questions and these themes were examined under three headings. When the teachers' views on the usability of the eTwinning platform were examined, the teachers stated that the platform was not useful and they had problems in communication $(f=8)$. Participating teachers find it difficult to use the eTwinning platform or those who think it is impractical, as well as those who think otherwise $(f=5)$.

When the teachers' opinions about the contribution of eTwinning platform to their professional development were analyzed, a total of 12 codes were reached as a result of the analysis of the data obtained. Make collaboration with colleagues " $(\mathrm{f}=13)$ is seen as the code with the highest frequency. This code is followed by learning new approaches and methods from colleagues " $(\mathrm{f}=12)$ and the code $\mathrm{f}$ Learning Web 2 tools $((\mathrm{f}=12)$ is followed with equal frequency. 
Looking at the teachers' views on their suggestions for the eTwinning platform, it is seen that the teachers offer many suggestions about the eTwinning platform. However, the most repeated proposal is the dissemination of the platform.

\section{Discussion and Conclusion}

Professional development process takes place in the lifelong learning process (Sarıdaş and Deniz, 2017). Professional development activities applied in our country are carried out online or face to face by the General Directorate of Teacher Training and Development. The number of teachers employed in these studies is limited for various reasons. With the number of teachers exceeding 1 million, it is not possible for all teachers to benefit from inservice trainings of the Ministry of National Education. Therefore, it is an appropriate solution for teachers to receive in-service trainings online. eTwinning provides online professional development for teachers and users at national and international levels. eTwinning offers teachers and students significant opportunities for the development of learning and innovation skills that are very important in the 21st Century. However, there may be some problems during use. As evidenced by the answers to the research questions, the suggestions expressed by the teachers about the use of the eTwinning platform address the problem of schools' internet connection. Bozdag (2017), in his research, concluded that despite the projects, improvements are needed in schools, especially in terms of the internet infrastructure. We also talked about the need to develop different ways to appreciate and reward the efforts of teachers who voluntarily carry out eTwinning projects and actively use technology for these projects. Similar expressions were also expressed by the teachers participating in the research and it was suggested that the teachers who make projects would be rewarded and the online trainings they take would be logged on Mebbis (Ö2).

\section{Araştırmanın Etik Taahhüt Metni}

“Çevrim İçi Bir Öğrenme Ortamı Olarak eTwinning Platformuna İlişkin Öğretmenlerin Görüş ve Değerlendirmeleri" başlıklı çalışmanın yazım sürecinde bilimsel, etik ve alıntı kurallarına uyulmuş; toplanan veriler üzerinde herhangi bir tahrifat yapılmamış, karşılaşılacak tüm etik ihlallerde "Cumhuriyet Uluslararası Eğitim Dergisi ve Editörünün" hiçbir sorumluluğunun olmadığı, tüm sorumluluğun Sorumlu Yazara ait olduğu ve bu çalışmanın herhangi başka bir akademik yayın ortamına değerlendirme için gönderilmemiş olduğunu taahhüt ederim.

\section{Authors' Biodata/Yazar Bilgileri}

Fatma AVCI Anadolu Üniversitesi Eğitim Bilimleri Anabilim Dalı, Eğitim Fakültesi Eğitim Programları ve Öğretim Programında doktora eğitimini tamamlamış ve Eskişehir-Tepebaşı Nermin Özdemir Anaokulunda yönetici olarak görev yapmaktadır.

Fatma Avc1 She completed her doctorate education in Anadolu University, Department of Educational Sciences, Faculty of Education, Education Programs and Education Program and works as a manager in Eskişehir-Tepebaşı Nermin Özdemir Kindergarten. 